\title{
On the special role of NCX in astrocytes: Translating Na+- transients into intracellular Ca2+ signals
}

DOI:

10.1016/j.ceca.2019.102154

\section{Document Version}

Accepted author manuscript

Link to publication record in Manchester Research Explorer

\section{Citation for published version (APA):}

Verkhratsky, A., Rose, C., \& Ziemens, D. (2020). On the special role of NCX in astrocytes: Translating Na+transients into intracellular Ca2+ signals. Cell calcium, 85(1), 102154. https://doi.org/10.1016/j.ceca.2019.102154

\section{Published in:}

Cell calcium

\section{Citing this paper}

Please note that where the full-text provided on Manchester Research Explorer is the Author Accepted Manuscript or Proof version this may differ from the final Published version. If citing, it is advised that you check and use the publisher's definitive version.

\section{General rights}

Copyright and moral rights for the publications made accessible in the Research Explorer are retained by the authors and/or other copyright owners and it is a condition of accessing publications that users recognise and abide by the legal requirements associated with these rights.

\section{Takedown policy}

If you believe that this document breaches copyright please refer to the University of Manchester's Takedown Procedures [http://man.ac.uk/04Y6Bo] or contact uml.scholarlycommunications@manchester.ac.uk providing relevant details, so we can investigate your claim.

\section{OPEN ACCESS}


On the special role of $\mathrm{NCX}$ in astrocytes:

\section{Translating $\mathrm{Na}^{+}$-transients into intracellular $\mathrm{Ca}^{2+}$ signals}

4

${ }^{1}$ Institute of Neurobiology, Faculty of Mathematics and Natural Sciences, Heinrich Heine University Duesseldorf, 40225 Duesseldorf, Germany M13 9PT, UK 48011, Bilbao, Spain;

* Corresponding author: Prof. Dr. Christine Rosemarie Rose, Institute of Neurobiology, Faculty of Mathematics and Natural Sciences, Heinrich Heine University Duesseldorf, Fax: ++49 (211) 81 13415; e-mail: rose@hhu.de 


\section{Abstract}

As a solute carrier electrogenic transporter, the sodium/calcium exchanger (NCX13/SLC8A1-A3) links the trans-plasmalemmal gradients of sodium and calcium ions $\left(\mathrm{Na}^{+}\right.$, $\mathrm{Ca}^{2+}$ ) to the membrane potential of astrocytes. Classically, NCX is considered to serve the export of $\mathrm{Ca}^{2+}$ at the expense of the $\mathrm{Na}^{+}$gradient, defined as a "forward mode" operation. Forward mode NCX activity contributes to $\mathrm{Ca}^{2+}$ extrusion and thus to the recovery from intracellular $\mathrm{Ca}^{2+}$ signals in astrocytes. The reversal potential of the NCX, owing to its transport stoichiometry of $3 \mathrm{Na}^{+}$to $1 \mathrm{Ca}^{2+}$, is, however, close to the astrocytes' membrane potential and hence even small elevations in the astrocytic $\mathrm{Na}^{+}$ concentration or minor depolarisations switch it into the "reverse mode" $\left(\mathrm{Ca}^{2+}-\right.$ import $/ \mathrm{Na}^{+}$export). Notably, transient $\mathrm{Na}^{+}$elevations in the millimolar range are induced by uptake of glutamate or GABA into astrocytes and/or by the opening of $\mathrm{Na}^{+}$-permeable ion channels in response to neuronal activity. Activity-related $\mathrm{Na}^{+}$transients result in NCX reversal, which mediates $\mathrm{Ca}^{2+}$ influx from the extracellular space, thereby generating astrocyte $\mathrm{Ca}^{2+}$ signalling independent from $\mathrm{InsP}_{3}$-mediated release from intracellular stores. Under pathological conditions, reverse $\mathrm{NCX}$ promotes cytosolic $\mathrm{Ca}^{2+}$ overload, while dampening $\mathrm{Na}^{+}$elevations of astrocytes. This review provides an overview on our current knowledge about this fascinating transporter and its special functional role in astrocytes. We shall delineate that $\mathrm{Na}^{+}$-driven, reverse NCX-mediated astrocyte $\mathrm{Ca}^{2+}$ signals are involved neurone-glia interaction. $\mathrm{Na}^{+}$transients, translated by the NCX into $\mathrm{Ca}^{2+}$ elevations, thereby emerge as a new signalling pathway in astrocytes. 
1 Key words: sodium, calcium, synapse, neurone-glia interaction, astroglial ionic 2 excitability 


\section{Highlights}

- Astrocytes express all three isoforms of the sodium/calcium exchanger (NCX); the transporters are preferentially located on perisynaptic processes and endfeet.

- $\mathrm{NCX}$ contributes to the regulation of $\mathrm{Na}^{+}$and $\mathrm{Ca}^{2+}$ concentrations in astrocytes at rest; in physiological conditions NCX transport direction fluctuates between forward and reverse mode.

- Transient increases in astrocyte $\mathrm{Na}^{+}$concentration resulting from neuronal activity and transmitter release drive the NCX into reverse mode, producing $\mathrm{Ca}^{2+}$ influx into astrocytes.

- $\mathrm{Na}^{+}$-driven $\mathrm{Ca}^{2+}$ signals generated by reverse $\mathrm{NCX}$ serve important functional roles in neurone-glia interaction. 


\section{Graphical Abstract}

2

3

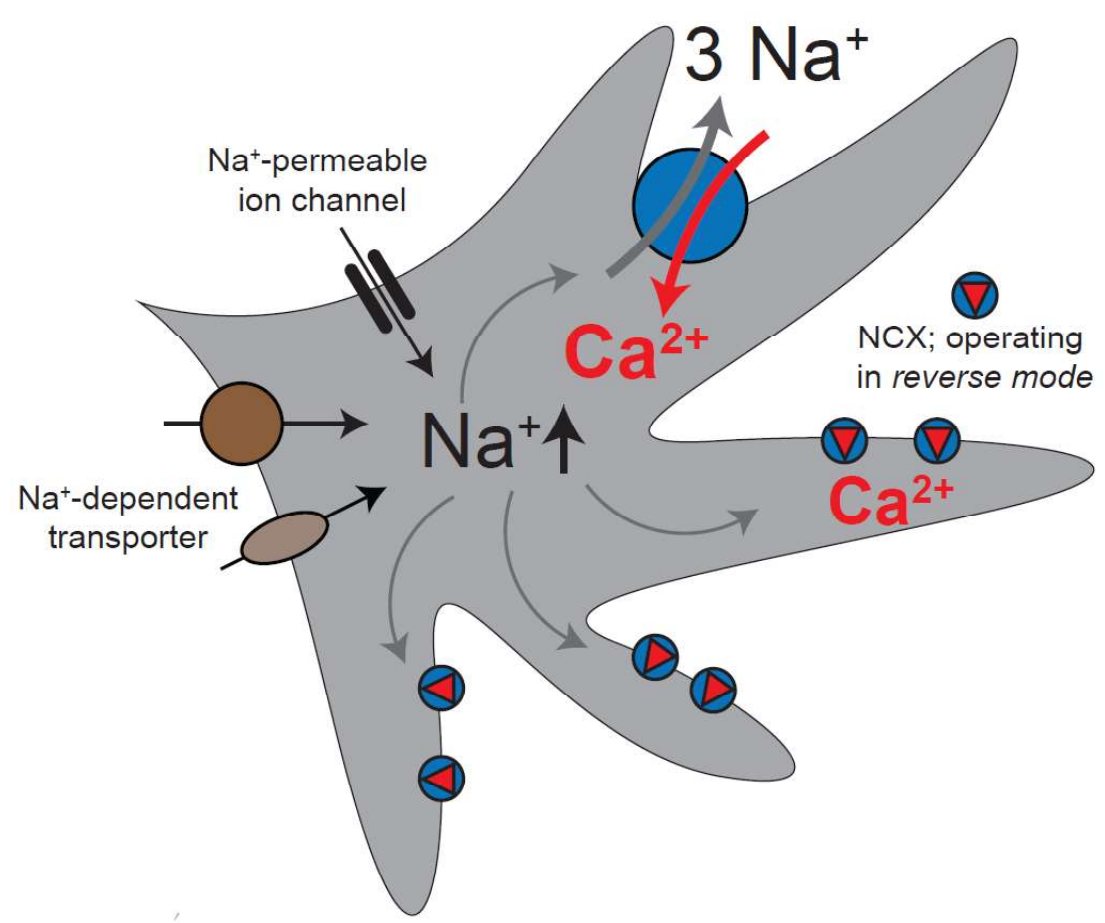

4

Astrocyte NCX couples the plasma membrane gradients of sodium and calcium ions $\left(\mathrm{Na}^{+}\right.$, $\mathrm{Ca}^{2+}$ ) to the membrane potential of astrocytes. Activity-related intracellular $\mathrm{Na}^{+}$transients result in a switch from forward into reverse mode, thereby generating astrocytic $\mathrm{Ca}^{2+}$

7 signals.

8 


\section{Introduction}

Astrocytes are electrically non-excitable cells, i.e. they do not generate fast regenerative electrical signals like neurones. Instead they rely upon dynamic changes in intracellular concentrations of ions, of which changes in $\mathrm{Ca}^{2+}$ and $\mathrm{Na}^{+}$are the best studied [1]. Intracellular $\mathrm{Ca}^{2+}$ signals, which can be transmitted to neighbouring cells, are instrumental in astroglial interaction with neurones $[2,3]$.

A classical route for the generation of astrocyte $\mathrm{Ca}^{2+}$ transients is through $\mathrm{Ca}^{2+}$ release from intracellular stores. This can happen in response to the binding of transmitters to metabotropic receptors, activation of $\mathrm{G}_{\mathrm{q}}$-proteins coupled to phospholipase $\mathrm{C}$, and the generation of $\mathrm{InsP}_{3}$ that activates $\mathrm{Ca}^{2+}$ channels of the endoplasmic reticulum [4]. Mitochondria represent another intracellular $\mathrm{Ca}^{2+}$ store which, in physiological conditions, can release $\mathrm{Ca}^{2+}$ through a mitochondrial sodium/calcium exchanger (NLCX) that can also transport lithium [5, 6] (Fig. 1A). Besides its release from intracellular stores, astroglial $\mathrm{Ca}^{2+}$ signals can be generated by an influx of $\mathrm{Ca}^{2+}$ from the extracellular space following the opening of ionotropic transmitter receptors, following operation of $\mathrm{Na}^{+}-$ gradient-driven transporters or following $\mathrm{Ca}^{2+}$ entry through other ion channels [3]. Whereas $\mathrm{InsP}_{3}$-mediated signalling seems to be predominant in astrocyte soma, the plasmalemmal entry pathways appear to be specifically relevant for $\mathrm{Ca}^{2+}$ signalling in astrocyte processes [7-11].

The recovery from increases in cytosolic $\mathrm{Ca}^{2+}$ concentration is mediated by its extrusion into the extracellular space by the plasma membrane $\mathrm{Ca}^{2+}$-ATPase (PCMA), by its transport into the endoplasmic reticulum by the SERCA pump, and by its uptake into mitochondria by a mitochondrial $\mathrm{Ca}^{2+}$ uniporter $[12,13]$. In addition, astrocytes express the sodium/calcium exchanger ( $\mathrm{NCX}$ isoforms 1-3) on their plasma membranes $[6,14$, 
15] (Fig. 1A). NCX contributes to the export of $\mathrm{Ca}^{2+}$ from the cytosol - but only at low baseline intracellular $\mathrm{Na}^{+}$concentration $\left(\left[\mathrm{Na}^{+}\right]_{\mathrm{i}}\right)$ as described below.

As a matter of fact, functions of NCX in astrocytes are not fully understood. As mentioned above, and established for many other cell types, the main role initially attributed to the NCX was to assist the PMCA in exporting $\mathrm{Ca}^{2+}$. In this so-called forward mode (Fig. 1A), the energy for $\mathrm{Ca}^{2+}$ export by the $\mathrm{NCX}$ is provided by the strong inwardly-directed $\mathrm{Na}^{+}$gradient given a low baseline $\left[\mathrm{Na}^{+}\right]_{\mathrm{i}}(\leq 10-12 \mathrm{mM})[15]$. Based on a wealth of recent experimental findings, however, this view has changed profoundly. Some studies have reported a higher baseline astrocyte $\left[\mathrm{Na}^{+}\right]_{\mathrm{i}}(\sim 15-17 \mathrm{mM})[16,17]$, under which condition NCX may fluctuate between forward and reverse mode (or even operate in the reverse mode at rest) (Fig. 1A). Moreover, there is convincing evidence that transient increases in astrocyte $\left[\mathrm{Na}^{+}\right]_{\mathrm{i}}$ which accompany neuronal activity $[1,16,17]$ readily drive reverse operation of NCX. This results in an increased influx of $\mathrm{Ca}^{2+}$, directly coupling astrocyte $\mathrm{Na}^{+}$transients to $\mathrm{Ca}^{2+}$ signalling.

NCX thereby emerges as a dynamic translator of astrocyte $\mathrm{Na}^{+}$signals, converting them into influx of $\mathrm{Ca}^{2+}$ from the extracellular space. In parallel, NCX shapes cytoplasmic $\mathrm{Na}^{+}$signalling by mediating $\mathrm{Na}^{+}$entry in the forward mode and extruding $\mathrm{Na}^{+}$in the reverse one. This review gives an overview on the special role of NCX in astrocytes with a main emphasis on its putative functions in the healthy brain and a synopsis on its role in ischemic conditions.

\section{Expression of NCX in astrocytes}

First direct evidence for a functional expression of NCX in astrocytes was obtained in cell cultures from rat brain, where a reduction in the transmembrane $\mathrm{Na}^{+}$gradient resulted 
in a (relatively minor) increase in the $\left[\mathrm{Ca}^{2+}\right]_{i}[18]$. Soon afterwards, NCX mRNA and protein were detected in cultured astrocytes $[19,20]$. It is now established that astrocytes express all three subtypes of the NCX gene family, NCX1-3 (SLC8A1-A3) [21-23]. Several splicing variants of NCX1 and 3 were also described in astrocytes [24-26].

Sharing a moderate sequence identity, the three NCX subtypes exhibit similar functional properties including apparent binding affinities to $\mathrm{Na}^{+}$and $\mathrm{Ca}^{2+}$, but display some differences in their requirement for the presence of ATP and their regulation by protein kinases [24, 27, 28]. Expression of NCX subtypes differs between brain regions, indicating specialised functions of these isoforms [29, 30]. The specific roles of the isoforms remain, however, unclear, partly because of a lack of isoform-specific inhibitors. Some general information has been acquired from knock-out animals. NCX3-deficient mice have a higher threshold for LTP induction and show deficits in hippocampusdependent spatial learning [31]. Mice lacking NCX2, in contrast, show increased LTP and an improvement in memory [32]. General knockout of NCX1 is lethal at embryonic stage [33], making thus an analysis of the effect of its complete removal in the postnatal brain impossible.

In contrast to the PMCA, which seems to be relatively uniformly expressed over the cell surface of astrocytes [34], NCX appears to be targeted to specialized areas of the cell. There is evidence from astrocytes in culture that NCX is preferentially expressed in regions of the plasma membrane in a close vicinity of the endoplasmic reticulum. These regions also contain an $\alpha 2$-containing $\mathrm{Na}^{+} / \mathrm{K}^{+}$-ATPase (NKA), and together with the latter, the NCX has been proposed to generate a local signalling compartment for $\mathrm{Ca}^{2+}$ and $\mathrm{Na}^{+}$, separated from the bulk of the cytosol [34-36]. In astrocytes in the rat brain 
tissue slices, preferential localization of $\mathrm{NCX}$ on astrocyte processes contacting glutamatergic synapses was similarly noted [21] (Fig. 1A, B). In addition, the latter study found NCX to be concentrated in astroglial endfeet plastering blood vessels (Fig. 1B). The perisynaptic processes of astrocytes are also rich in $\mathrm{Na}^{+}$-dependent glutamate transporters, which generate substantial $\mathrm{Na}^{+}$influx during neuronal activity [37, 38] Based on these anatomical findings, it seems that reverse-mode NCX might serve to provide $\mathrm{Ca}^{2+}$ influx into perisynaptic astrocyte processes in response to excitatory synaptic activity [21,39]. The latter suggestion is in line with NCX' proposed function translating activity-related astrocyte $\mathrm{Na}^{+}$transients into intracellular $\mathrm{Ca}^{2+}$ signals as detailed below.

\section{Properties of NCX under physiological conditions}

\subsection{Transport direction and involvement of $\mathrm{NCX}$ to ion homeostasis at resting} conditions

Based on a transport stoichiometry of $3 \mathrm{Na}^{+}: 1 \mathrm{Ca}^{2+}$, the equilibrium potential of the NCX can be calculated from the Nernst-equilibrium potentials of $\mathrm{Na}^{+}\left(\mathrm{E}_{\mathrm{Na}}\right)$ and $\mathrm{Ca}^{2+}\left(\mathrm{E}_{\mathrm{Ca}}\right)$ according to the following equation: $\mathrm{E}_{\mathrm{NCX}}=3 \mathrm{E}_{\mathrm{Na}}-2 \mathrm{E}_{\mathrm{Ca}}[14,15]$. In astrocytes, $\mathrm{E}_{\mathrm{NCX}}$ and NCX operational modality are thus largely determined by the $\left[\mathrm{Na}^{+}\right]_{\mathrm{i}}$. For extracellular concentrations of $2 \mathrm{mM} \mathrm{Ca}^{2+}$ and $150 \mathrm{mM} \mathrm{Na}^{+}$, and at baseline $\left[\mathrm{Na}^{+}\right]_{\mathrm{i}}$ of $12 \mathrm{mM}$ and $\left[\mathrm{Ca}^{2+}\right]_{\mathrm{i}}$ of $80 \mathrm{nM}$ (values taken from [40]), $\mathrm{E}_{\mathrm{NCX}}$ equals $-64 \mathrm{mV}$ at room temperature. Because the latter value is more positive than the typical membrane potential of astrocytes $\left(-85 \mathrm{mV}\right.$; see [40]), NCX will operate in the forward mode $\left(\mathrm{Ca}^{2+}\right.$ export $/ \mathrm{Na}^{+}$ import), mediating a net influx of positive change under these conditions. This is 
illustrated schematically in Fig. 1C, which depicts the calculated current of the NCX of neocortical astrocytes in dependence of $\left[\mathrm{Na}^{+}\right]_{i}$ and $\left[\mathrm{Ca}^{2+}\right]_{\mathrm{i}}$ at $-85 \mathrm{mV}$ (green dot) [40]. However at slightly higher baseline $\left[\mathrm{Na}^{+}\right]$, for example at $17 \mathrm{mM}$ (red dot), $\mathrm{E}_{\mathrm{NCX}}$ shifts to a more negative value of $-91 \mathrm{mV}$. This results in a driving force favouring its operation in the reverse mode, which is further augmented by plasma membrane depolarization (Fig. $1 \mathrm{C}$; right). Hence in physiological conditions, NCX operates close to its reversal potential and, depending on the exact baseline $\left[\mathrm{Na}^{+}\right]_{i}$ and membrane potential fluctuates between forward and reverse mode.

These calculations illustrate the intriguing dependence of NCX transport direction on $\left[\mathrm{Na}^{+}\right]_{i}$ of astrocytes. Notably, baseline $\left[\mathrm{Na}^{+}\right]_{i}$ of astrocytes of mouse hippocampus and neocortex as determined in different studies does cover this range: values between 12 and $17 \mathrm{mM}$ were reported for cells in acute tissue slices as well as for cells in primary cultures (e. g. [40-48]). These measurements further corroborate the dynamic nature of NCX operation between two modes.

Imaging studies using pharmacological inhibitors of NCX [49] add to this reasoning. An established inhibitor of NCX is 2-[2-[4-(4nitrobenzyloxy)phenyl]ethyl]isothiourea (KB-R7943) [50, 51]. Exposure to KB-R7943 induced an increase in $\left[\mathrm{Ca}^{2+}\right]_{i}$ in astrocytes of the olfactory bulb, hippocampus and in glioblastoma cells, suggesting that NCX worked in the forward mode extruding $\mathrm{Ca}^{2+}[52-$ 54]. Conversely, astrocytes cultured from rat visual cortex and cerebellum responded with a decrease in $\left[\mathrm{Ca}^{2+}\right]_{\mathrm{i}}$ following administration of KB-R7943, indicating its operation in the reverse mode $[44,46]$. The same phenomenon was observed in astrocytes in organotypic cell culture treated with the NCX inhibitor YM-244769 [55] (Fig. 2C). 
Finally, others reported only a minor influence of NCX inhibition on baseline $\left[\mathrm{Ca}^{2+}\right]_{\mathrm{i}}$ in astrocytes [56]; this most likely happens when resting membrane potential roughly equals $\mathrm{E}_{\mathrm{NCX}}$. These conflicting (and yet internally consistent) results emphasize the notion that NCX in astrocytes at rest fluctuates between forward and reverse mode depending on $\left[\mathrm{Ca}^{2+}\right]_{\mathrm{i}},\left[\mathrm{Na}^{+}\right]_{\mathrm{i}}$ and $\mathrm{V}_{\mathrm{m}}$.

A correct prediction of NCX transport direction in astrocytes is further complicated by the fact that the above-mentioned values for $\left[\mathrm{Na}^{+}\right]_{\mathrm{i}}$ represent bulk measurements from cell bodies. A recent study on HEK cells employing fluorescence lifetime imaging (FLIM) provided evidence that the $\mathrm{Na}^{+}$concentration $\left(\left[\mathrm{Na}^{+}\right]\right)$of nuclei is significantly lower than that of the surrounding cytosol [57]. Moreover, a region with significantly higher 12 was detected around the nucleus, presumably reflecting higher $\left[\mathrm{Na}^{+}\right]$in peri-nuclear mitochondria [57]. While such information is not available for astrocytes yet, a former study is in line with such heterogeneity reporting that mitochondria in astrocytes have a significantly higher $\left[\mathrm{Na}^{+}\right]$than the cytosol $(19 \mathrm{mM}$ versus $13 \mathrm{mM}$ ) [43].

Furthermore, it is also unclear whether somatic $\left[\mathrm{Na}^{+}\right]$accurately reflects $\left[\mathrm{Na}^{+}\right]$in small processes or if perisynaptic processes close to synapses or perivascular endfeet may exhibit a different (probably higher?) $\left[\mathrm{Na}^{+}\right]$. Experiments in silico indicate that perisynaptic microdomains represent distinct signalling compartments of astrocytes that favour $\mathrm{Ca}^{2+}$ influx through reverse NCX [58-61]. Similarly, endfeet were shown to exhibit slower diffusion dynamics than other astrocyte processes [62] and might maintain a $\left[\mathrm{Na}^{+}\right]$different from other parts of the cell. 
Finally, earlier work also suggested the presence of a local ionic signalling compartment between the plasma membrane and the ER of astrocytes [34-36]. These findings imply that different sub-cellular astrocyte compartments may differ in their $\left[\mathrm{Na}^{+}\right]$. This is even more so because $\mathrm{Na}^{+}$flux across the plasma membrane may predominately occur in nanodomains close to the plasma membrane [34] and thus escape conventional approaches for $\mathrm{Na}^{+}$detection such as fluorescence imaging with soluble chemical indicator dyes. As illustrated above, small differences in $\left[\mathrm{Na}^{+}\right]_{\mathrm{i}}$ in the $\mathrm{mM}$ range will significantly shift $\mathrm{E}_{\mathrm{NCX}}$, resulting in different modes of NCX operation (Fig. 1C).

In conclusion these considerations show that the transport direction of plasma membrane NCX in astrocytes at rest has a dynamic behaviour. This is largely due to the fact that it strongly depends on the $\left[\mathrm{Na}^{+}\right]_{\mathrm{i}}$, and switches between forward and reverse mode within a narrow range of $\left[\mathrm{Na}^{+}\right]_{\mathrm{i}}(12-17 \mathrm{mM})$. It is probably safe to assume that baseline $\left[\mathrm{Na}^{+}\right]_{\mathrm{i}}$ of astrocytes, and thus NCX transport direction, may vary in this range depending on the brain region or among different cells and/or cellular sub-compartments of one particular region. Of note, similar conclusion was made for cultured neocortical neurones, in which NCX "might concurrently operate in both the forward and the reverse direction, perhaps in different subcellular location" [63]. Therefore in astrocytes, NCX does fluctuate between transport directions driven by small fluctuations in $\left[\mathrm{Na}^{+}\right]_{\mathrm{i}}$ within distinct sub-cellular compartments. While at present there are no reports suggesting "spontaneous" $\left[\mathrm{Na}^{+}\right]_{\mathrm{i}}$ oscillations in astrocytes, neuronal activity triggers transient $\left[\mathrm{Na}^{+}\right]_{\mathrm{i}}$ increases thereby affecting NCX reversal as described below.

\subsection{Activation of $\mathrm{NCX}$ in response to ionic signalling}

\subsubsection{Contribution of forward NCX to recovery of $\left[\mathrm{Ca}^{2+}\right]_{i}$ transients}


As elaborated above and schematically illustrated in Fig. 1C, the transport direction of NCX depends on both, $\mathrm{Na}^{+}$and the $\mathrm{Ca}^{2+}$ transmembrane gradients, as well as on the membrane potential of astrocytes. Fig. 1C also predicts that activity-related increases in $\left[\mathrm{Ca}^{2+}\right]_{\mathrm{i}}$ without concomitant increases in $\left[\mathrm{Na}^{+}\right]_{\mathrm{i}}$ result in an increase in the NCX inward current (and $\mathrm{Na}^{+}$influx) resulting from enhanced forward mode activity. At low $\left[\mathrm{Na}^{+}\right]_{\mathrm{i}}$, NCX therefore extrudes $\mathrm{Ca}^{2+}$, contributing to the $\mathrm{Ca}^{2+}$ signals' recovery (Fig. 1A, 4A) [64]. In other words, NCX activity dampens astrocyte $\left[\mathrm{Ca}^{2+}\right]_{\mathrm{i}}$ transients, if these are not accompanied by substantial rise in $\left[\mathrm{Na}^{+}\right]_{\mathrm{i}}$.

Forward operation of NCX is indeed required for $\mathrm{Ca}^{2+}$ homeostasis in glioblastoma cells, which undergo increased $\mathrm{Ca}^{2+}$-mediated cell death when treated with NCX inhibitors [52]. Such a role is similar to the proposed function of NCX in other tissues including skeletal muscle and heart as a "low-affinity-high-capacity" $\mathrm{Ca}^{2+}$ exporter [65].

\subsection{2 $\mathrm{Ca}^{2+}$ influx by reverse $\mathrm{NCX}$ contributes to astrocyte $\left[\mathrm{Ca}^{2+}\right]_{\mathrm{i}}$ signalling}

There is a wealth of experimental evidence obtained from astrocytes of different brain regions, both in culture and in acutely isolated tissue slices, demonstrating that neuronal activity, application of exogenous glutamate, agonists of ionotropic glutamate receptors or glutamate transporters result in a transient rise of astrocytic $\left[\mathrm{Na}^{+}\right]_{i}[1,66]$ (Fig. 2A). Moreover, it is established that increases in astrocyte $\left[\mathrm{Na}^{+}\right]_{\mathrm{i}}$ (with or without concomitant $\left[\mathrm{Ca}^{2+}\right]_{\mathrm{i}}$ signalling) switch NCX into the reverse mode, generating $\mathrm{Ca}^{2+}$ influx.

$\mathrm{Na}^{+}$-driven reversal of NCX occurs in response to $\mathrm{Na}^{+}$influx through various plasmalemmal ion channels. Reverse NCX for example contributed to astrocytic $\mathrm{Ca}^{2+}$ 
elevations following mechanical stimulation $[46,67,68]$ and augmented $\mathrm{Ca}^{2+}$ signals induced by application of low doses of glutamate and ATP [69]. $\mathrm{Ca}^{2+}$ influx through reverse NCX triggered glutamate release in cultured cortical astrocytes and was potentiated by their depolarization [70]. In Bergmann glial cells [71] and in astrocytes in culture [72], $\mathrm{Ca}^{2+}$ influx mediated by reverse $\mathrm{NCX}$ was demonstrated following the opening of AMPA receptor channels. In astrocytes in acute neocortical tissue slices, $\mathrm{Na}^{+}$ entry through NMDA-receptors promoted NCX reversal, significantly prolonging accompanying $\left[\mathrm{Ca}^{2+}\right]_{\mathrm{i}}$ transients $[40]$ (Fig. 2B). Finally, $\left[\mathrm{Ca}^{2+}\right]_{\mathrm{i}}$ elevations induced by the opening of channelrhodopsin-2 expressed in astrocytes were reported to be mainly due to $\mathrm{Na}^{+}$-dependent reversal of NCX [73].

Besides $\mathrm{Na}^{+}$influx through ion channels, significant $\left[\mathrm{Na}^{+}\right]_{\mathrm{i}}$ increases in astrocytes are induced by operation of $\mathrm{Na}^{+}$-dependent transporters. Particularly prominent $\mathrm{Na}^{+}$ influx is mediated by the high-affinity-glutamate transporters EAAT1/SLC1A6 and EAAT2/SLC1A2 (known as GLAST and GLT-1 in experiments in rodents), which import $3 \mathrm{Na}^{+}$together with glutamate $[74,75]$. Activation of $\mathrm{Na}^{+}$-dependent glutamate uptake and accompanying $\left[\mathrm{Na}^{+}\right]_{\mathrm{i}}$ increases resulted in reversal of $\mathrm{NCX}$ and $\mathrm{Ca}^{2+}$ influx into astrocytes; the NCX-mediated $\mathrm{Ca}^{2+}$ influx was further amplified by $\mathrm{Ca}^{2+}$-induced $\mathrm{Ca}^{2+}$ release from the endoplasmatic reticulum [76]. $\mathrm{Ca}^{2+}$ influx through reverse NCX following a $\left[\mathrm{Na}^{+}\right]_{\mathrm{i}}$ increase in response to activation of glutamate transporters was suggested to be a main source of $\left[\mathrm{Ca}^{2+}\right]_{\mathrm{i}}$ transients in fine astrocyte processes (Fig. 2C)) $[55,77]$. This NCX-mediated interplay between glutamate-transport-induced $\left[\mathrm{Na}^{+}\right]_{\mathrm{i}}$ increases and $\left[\mathrm{Ca}^{2+}\right]_{i}$ signalling was proposed to result in the $\mathrm{Ca}^{2+}$-dependent arrest of mitochondria in perisynaptic astrocyte processes close to active synapses $[78,79]$. The 
latter mechanism couples the synaptic release of glutamate and resulting astroglial $\mathrm{Na}^{+}$ signals to the availability of ATP in astrocyte processes, and may, therefore, represent a key process in the neuro-glial metabolic coupling [80].

Similar to glutamate transport, uptake of GABA by astrocytes is coupled to the influx of $\mathrm{Na}^{+}$[81]. Because GABA is co-transported with only $2 \mathrm{Na}^{+}$, activation of GABA transport produces smaller elevations in astrocyte $\left[\mathrm{Na}^{+}\right]_{\mathrm{i}}$ as compared to glutamate transporters $[82,83]$. Nonetheless, experiments on hippocampal tissue slices provide convincing evidence that a $\left[\mathrm{Na}^{+}\right]_{i}$ rise generated by operation of the astrocytic GABA transporter GAT-3/SLC6A11 reverses NCX, thus producing a $\left[\mathrm{Ca}^{2+}\right]_{\mathrm{i}}$ increase (Fig. 2D). This $\left[\mathrm{Ca}^{2+}\right]_{\mathrm{i}}$ elevation was claimed to trigger the release of ATP and adenosine from astrocytes, which activated adenosine receptors on nearby presynaptic terminals, resulting in a depression of glutamatergic synaptic input [53]. In the olfactory bulb, GABAergic signalling activates astrocyte GABA uptake and resulting $\left[\mathrm{Na}^{+}\right]_{\mathrm{i}}$ increases led to a NCXmediated $\left[\mathrm{Ca}^{2+}\right]_{\mathrm{i}}$ influx sufficient to trigger $\mathrm{Ca}^{2+}$-induced $\mathrm{Ca}^{2+}$ release [54]. GABArelated transient $\mathrm{Na}^{+}$elevations are thus directly translated into astrocyte $\mathrm{Ca}^{2+}$ signals in these two different systems.

Astroglial $\mathrm{Na}^{+}$-bicarbonate co-transporter NBCe1/SLC4A4 is another pathway generating $\left[\mathrm{Na}^{+}\right]_{\mathrm{i}}$ elevations $[84,85]$. In the brainstem, NBCe1 is activated by extracellular acidification. In response to the resulting $\mathrm{Na}^{+}$entry, $\left[\mathrm{Na}^{+}\right]_{\mathrm{i}}$ increases switch NCX to reverse mode, generating $\mathrm{Ca}^{2+}$ signalling that facilitates the release of ATP from astrocytes. This $\mathrm{Na}^{+}$-triggered, $\mathrm{Ca}^{2+}$-dependent release of ATP is involved in the adaptive response of the neuronal network to changes in the $\mathrm{P}_{\mathrm{CO} 2}[86]$. 
In addition to the above-mentioned transporters and channels, a multitude of other

\section{Role of NCX under ischemic conditions}

The role of NCX under pathological conditions has been addressed in the context of various neurological diseases including those related to glutamate excitotoxicity and ischemic stroke $[15,88-90]$. The specific involvement of the three isoforms in ischemic injury was studied using different animal models.

Manipulations with expression of NCX1 clearly indicated that it serves a protective role in brain ischemia [91-93]. The same is true for NCX2, because mice lacking this isoform exhibit an increased vulnerability to cerebral ischemia [94] (Fig. 3A). Suppression of the NCX3 gene in mice results in massive neuronal death and aggravates brain damage after ischemia [93, 95] (Fig. 3B). In cerebellar granule neurones, $\mathrm{Ca}^{2+}$ overload and excitotoxicity were increased by RNA interference to silence NCX3, indicating an increased vulnerability in the absence of this transporter related to a disturbance of intracellular ion homeostasis [96].

These and other studies suggest a generally neuroprotective role of NCX. Notably, however, the neuroprotective effects do not seem to involve counteracting excitotoxic 
1 cellular $\mathrm{Ca}^{2+}$ overloading. To the contrary, there is ample evidence for $\mathrm{Na}^{+}$-driven reversal of $\mathrm{NCX}$, generating $\left[\mathrm{Ca}^{2+}\right]_{\mathrm{i}}$ elevations under ischemic conditions both in situ as well as in vivo [45, 76, 97-101]. Notably, while generating substantial $\mathrm{Ca}^{2+}$ influx during metabolic inhibition, reverse NCX also dampened $\mathrm{Na}^{+}$influx into astrocytes in tissue slices of mouse cortex [101] (Fig. 3C).

The reported beneficial effects of NCX in different models for ischemic stroke are thus likely to be related to its ability to export $\mathrm{Na}^{+}$and to counteract the cellular $\mathrm{Na}^{+}$ loading and depolarization accompanying ischemia. Further studies, however, are required to address the specific role of astrocyte NCX under pathological conditions, using animal models with an astrocyte-specific deletion of NCX isoforms.

\section{Conclusions}

There is firm evidence for expression of NCX in astrocytes. Upon generation of astrocyte $\left[\mathrm{Ca}^{2+}\right]_{\mathrm{i}}$ signalling, NCX can serve as a $\mathrm{Ca}^{2+}$ exporter, but only if baseline $\left[\mathrm{Na}^{+}\right]_{\mathrm{i}}$ is low and in the absence of additional cellular $\mathrm{Na}^{+}$elevations (Fig. 4A). Because of its stoichiometry of $3 \mathrm{Na}^{+}$to $1 \mathrm{Ca}^{2+}$, NCX reversal potential is rather close to the membrane potential and its transport direction largely governed by subtle changes in $\left[\mathrm{Na}^{+}\right]_{\mathrm{i}}$ and $\mathrm{V}_{\mathrm{m}}$. Indeed, small fluctuations (several $\mathrm{mM}$ ) in $\left[\mathrm{Na}^{+}\right]_{\mathrm{i}}$ rapidly switch NCX between forward and reverse mode (or silence transport altogether when $\mathrm{E}_{\mathrm{NCX}}$ equals $\mathrm{V}_{\mathrm{m}}$ ). Neuronal activity is accompanied by transient increases in astrocyte $\left[\mathrm{Na}^{+}\right]_{\mathrm{i}}$ resulting from activation of $\mathrm{Na}^{+}$-dependent transporters and/or channel-mediated $\mathrm{Na}^{+}$influx. There is overwhelming evidence that these $\left[\mathrm{Na}^{+}\right]_{\mathrm{i}}$ transients switch NCX into reverse mode, generating thus $\mathrm{Ca}^{2+}$ influx (Fig. 4B). In the light of this direct functional coupling 
1 between the two ions, it seems appropriate to conclude that $\left[\mathrm{Na}^{+}\right]_{\mathrm{i}}$ transients in astrocytes,

2 directly translated by reverse $\mathrm{NCX}$ into $\left[\mathrm{Ca}^{2+}\right]_{\mathrm{i}}$ elevations, represent a new form of 3 cellular signalling, influencing astrocyte properties and playing a role in neuron-glia 4 interaction. 
Funding:

2

This work was supported by the Deutsche Forschungsgemeinschaft (FOR 2795:

3 Ro2327/13-1).

4

5

6

\section{Conflict of interest}

7

The authors declare no conflict of interest and no competing financial interest.

8

9

10

Author contributions

11

All authors have contributed to the first version of the manuscript and approved the final

12 article. 


\section{References}

[1] A. Verkhratsky, V. Untiet, C.R. Rose, Ionic signalling in astroglia beyond calcium, J Physiol, (2019).

[2] A. Araque, G. Carmignoto, P.G. Haydon, S.H. Oliet, R. Robitaille, A. Volterra, Gliotransmitters Travel in Time and Space, Neuron, 81 (2014) 728-739.

[3] A. Verkhratsky, M. Nedergaard, Physiology of Astroglia, Physiol Rev, 98 (2018) 239-389.

[4] A. Panatier, R. Robitaille, Astrocytic mGluR5 and the tripartite synapse, Neuroscience, 323 (2016) 29-34.

[5] R. Palty, W.F. Silverman, M. Hershfinkel, T. Caporale, S.L. Sensi, J. Parnis, C. Nolte, D. Fishman, V. Shoshan-Barmatz, S. Herrmann, D. Khananshvili, I. Sekler, NCLX is an essential component of mitochondrial $\mathrm{Na}^{+} / \mathrm{Ca}^{2+}$ exchange, Proc Natl Acad Sci U S A, 107 (2010) 436-441.

[6] V. Parpura, I. Sekler, R. Fern, Plasmalemmal and mitochondrial Na-Ca exchange in neuroglia, Glia, 64 (2016) 1646-1654.

[7] A. Volterra, N. Liaudet, I. Savtchouk, Astrocyte $\mathrm{Ca}(2+)$ signalling: an unexpected complexity, Nat Rev Neurosci, 15 (2014) 327-335.

[8] B.S. Khakh, K.D. McCarthy, Astrocyte calcium signaling: from observations to functions and the challenges therein, Cold Spring Harbor perspectives in biology, 7 (2015) a020404.

[9] D.A. Rusakov, Disentangling calcium-driven astrocyte physiology, Nat Rev Neurosci, $16(2015)$ 226-233. 
[10] E. Shigetomi, S. Patel, B.S. Khakh, Probing the Complexities of Astrocyte Calcium Signaling, Trends Cell Biol, 26 (2016) 300-312.

[11] A. Semyanov, Spatiotemporal pattern of calcium activity in astrocytic network, Cell Calcium, 78 (2019) 15-25.

[12] D. Guerini, L. Coletto, E. Carafoli, Exporting calcium from cells, Cell Calcium, 38 (2005) 281-289.

[13] M. Brini, E. Carafoli, The plasma membrane $\mathrm{Ca}(2)+$ ATPase and the plasma membrane sodium calcium exchanger cooperate in the regulation of cell calcium, Cold Spring Harbor perspectives in biology, 3 (2011).

[14] M.P. Blaustein, W.J. Lederer, Sodium/calcium exchange: its physiological implications, Physiol Rev, 79 (1999) 763-854.

[15] D. Khananshvili, Sodium-calcium exchangers (NCX): molecular hallmarks underlying the tissue-specific and systemic functions, Pflugers Arch, 466 (2014) 43-60.

[16] S. Kirischuk, V. Parpura, A. Verkhratsky, Sodium dynamics: another key to astroglial excitability?, Trends Neurosci, 35 (2012) 497-506.

[17] C.R. Rose, C. Karus, Two sides of the same coin: sodium homeostasis and signaling in astrocytes under physiological and pathophysiological conditions, Glia, 61 (2013) 1191-1205.

[18] M.P. Blaustein, W.F. Goldman, G. Fontana, B.K. Krueger, E.M. Santiago, T.D. Steele, D.N. Weiss, P.J. Yarowsky, Physiological roles of the sodium-calcium exchanger in nerve and muscle, Ann N Y Acad Sci, 639 (1991) 254-274. 
[19] K. Takuma, T. Matsuda, H. Hashimoto, S. Asano, A. Baba, Cultured rat astrocytes possess $\mathrm{Na}(+)-\mathrm{Ca} 2+$ exchanger, Glia, 12 (1994) 336-342.

[20] W.F. Goldman, P.J. Yarowsky, M. Juhaszova, B.K. Krueger, M.P. Blaustein, Sodium/calcium exchange in rat cortical astrocytes, J Neurosci, 14 (1994) 58345843.

[21] A. Minelli, P. Castaldo, P. Gobbi, S. Salucci, S. Magi, S. Amoroso, Cellular and subcellular localization of $\mathrm{Na}+-\mathrm{Ca} 2+$ exchanger protein isoforms, $\mathrm{NCX} 1, \mathrm{NCX} 2$, and NCX3 in cerebral cortex and hippocampus of adult rat, Cell Calcium, 41 (2007) 221-234.

[22] T. Thurneysen, D.A. Nicoll, K.D. Philipson, H. Porzig, Sodium/calcium exchanger subtypes NCX1, NCX2 and NCX3 show cell-specific expression in rat hippocampus cultures, Brain Res Mol Brain Res, 107 (2002) 145-156.

[23] M. Sakaue, H. Nakamura, I. Kaneko, Y. Kawasaki, N. Arakawa, H. Hashimoto, Y. Koyama, A. Baba, T. Matsuda, $\mathrm{Na}(+)-\mathrm{Ca}(2+)$ exchanger isoforms in rat neuronal preparations: different changes in their expression during postnatal development, Brain Res, 881 (2000) 212-216.

[24] D.H. Schulze, S.K. Polumuri, T. Gille, A. Ruknudin, Functional regulation of alternatively spliced $\mathrm{Na}+/ \mathrm{Ca} 2+$ exchanger (NCX1) isoforms, Ann N Y Acad Sci, 976 (2002) 187-196.

[25] S. He, A. Ruknudin, L.L. Bambrick, W.J. Lederer, D.H. Schulze, Isoform-specific regulation of the $\mathrm{Na}+/ \mathrm{Ca} 2+$ exchanger in rat astrocytes and neurons by PKA, $\mathrm{J}$ Neurosci, 18 (1998) 4833-4841. 
[26] B.D. Quednau, D.A. Nicoll, K.D. Philipson, Tissue specificity and alternative splicing of the $\mathrm{Na}+/ \mathrm{Ca} 2+$ exchanger isoforms NCX1, NCX2, and NCX3 in rat, Am J Physiol, 272 (1997) C1250-1261.

[27] A. Secondo, I.R. Staiano, A. Scorziello, R. Sirabella, F. Boscia, A. Adornetto, L.M. Canzoniero, G. Di Renzo, L. Annunziato, The Na+/Ca2+ exchanger isoform 3 (NCX3) but not isoform 2 (NCX2) and 1 (NCX1) singly transfected in BHK cells plays a protective role in a model of in vitro hypoxia, Ann N Y Acad Sci, 1099 (2007) 481-485.

[28] B. Linck, Z. Qiu, Z. He, Q. Tong, D.W. Hilgemann, K.D. Philipson, Functional comparison of the three isoforms of the $\mathrm{Na}+/ \mathrm{Ca} 2+$ exchanger $(\mathrm{NCX} 1, \mathrm{NCX} 2$, NCX3), Am J Physiol, 274 (1998) C415-423.

[29] P.C. Cheng, Y.S. Chen, R.C. Huang, $\mathrm{Na}(+) / \mathrm{Ca}(2)(+)$ Exchanger $2(\mathrm{NCX} 2)$ in the Circadian Clock of the Rat Suprachiasmatic Nucleus: Colocalization with Neuropeptides and Daily Profiles of Gene Expression and Protein Levels, The Chinese journal of physiology, 60 (2017) 215-225.

[30] M. Papa, A. Canitano, F. Boscia, P. Castaldo, S. Sellitti, H. Porzig, M. Taglialatela, L. Annunziato, Differential expression of the $\mathrm{Na}+-\mathrm{Ca} 2+$ exchanger transcripts and proteins in rat brain regions, J Comp Neurol, 461 (2003) 31-48.

[31] P. Molinaro, D. Viggiano, R. Nistico, R. Sirabella, A. Secondo, F. Boscia, A. Pannaccione, A. Scorziello, B. Mehdawy, S. Sokolow, A. Herchuelz, G.F. Di Renzo, L. Annunziato, Na+ -Ca2+ exchanger (NCX3) knock-out mice display an impairment in hippocampal long-term potentiation and spatial learning and memory, J Neurosci, 31 (2011) 7312-7321. 
[32] D. Jeon, Y.M. Yang, M.J. Jeong, K.D. Philipson, H. Rhim, H.S. Shin, Enhanced learning and memory in mice lacking $\mathrm{Na}+/ \mathrm{Ca} 2+$ exchanger 2, Neuron, 38 (2003) 965-976.

[33] H. Reuter, S.A. Henderson, T. Han, R.S. Ross, J.I. Goldhaber, K.D. Philipson, The $\mathrm{Na}+-\mathrm{Ca} 2+$ exchanger is essential for the action of cardiac glycosides, Circ Res, 90 (2002) 305-308.

[34] M.P. Blaustein, M. Juhaszova, V.A. Golovina, P.J. Church, E.F. Stanley, Na/Ca exchanger and PMCA localization in neurons and astrocytes: functional implications, Ann N Y Acad Sci, 976 (2002) 356-366.

[35] M.Y. Lee, H. Song, J. Nakai, M. Ohkura, M.I. Kotlikoff, S.P. Kinsey, V.A. Golovina, M.P. Blaustein, Local subplasma membrane $\mathrm{Ca} 2+$ signals detected by a tethered Ca2+ sensor, Proc Natl Acad Sci U S A, 103 (2006) 13232-13237.

[36] V. Golovina, H. Song, P. James, J. Lingrel, M. Blaustein, Regulation of Ca2+ signaling by $\mathrm{Na}+$ pump alpha-2 subunit expression, Ann N Y Acad Sci, 986 (2003) 509-513.

[37] K.P. Lehre, N.C. Danbolt, The number of glutamate transporter subtype molecules at glutamatergic synapses: chemical and stereological quantification in young adult rat brain, J Neurosci, 18 (1998) 8751-8757.

[38] R.J. Vandenberg, R.M. Ryan, Mechanisms of glutamate transport, Physiol Rev, 93 (2013) 1621-1657.

[39] C.R. Rose, A. Verkhratsky, Glial ionic excitability: The role for sodium, Glia, 64 (2016) 1609-1610. 
[40] D. Ziemens, F. Oschmann, N.J. Gerkau, C.R. Rose, Heterogeneity of ActivityInduced Sodium Transients between Astrocytes of the Mouse Hippocampus and Neocortex: Mechanisms and Consequences, J Neurosci, 39 (2019) 2620-2634.

[41] J. Langer, J. Stephan, M. Theis, C.R. Rose, Gap junctions mediate intercellular spread of sodium between hippocampal astrocytes in situ, Glia, 60 (2012) 239-252.

[42] T. Kelly, C.R. Rose, Ammonium influx pathways into astrocytes and neurones of hippocampal slices, J Neurochem, 115 (2010) 1123-1136.

[43] Y. Bernardinelli, G. Azarias, J.Y. Chatton, In situ fluorescence imaging of glutamate-evoked mitochondrial $\mathrm{Na}^{+}$responses in astrocytes, Glia, 54 (2006) 460470.

[44] H. Rojas, M. Ramos, R. Dipolo, A genistein-sensitive $\mathrm{Na}^{+} / \mathrm{Ca}^{2+}$ exchange is responsible for the resting $\left[\mathrm{Ca}^{2+}\right]_{i}$ and most of the $\mathrm{Ca}^{2+}$ plasma membrane fluxes in stimulated rat cerebellar type 1 astrocytes, Jpn J Physiol, 54 (2004) 249-262.

[45] B. Lenart, D.B. Kintner, G.E. Shull, D. Sun, Na-K-Cl cotransporter-mediated intracellular $\mathrm{Na}^{+}$accumulation affects $\mathrm{Ca}^{2+}$ signaling in astrocytes in an in vitro ischemic model, J Neurosci, 24 (2004) 9585-9597.

[46] R.C. Reyes, A. Verkhratsky, V. Parpura, Plasmalemmal $\mathrm{Na}^{+} / \mathrm{Ca}^{2+}$ exchanger modulates $\mathrm{Ca}^{2+}$-dependent exocytotic release of glutamate from rat cortical astrocytes, ASN neuro, 4 (2012) doi: 10.1042/AN20110059.

[47] P. Unichenko, O. Myakhar, S. Kirischuk, Intracellular $\mathrm{Na}(+)$ concentration influences short-term plasticity of glutamate transporter-mediated currents in neocortical astrocytes, Glia, 60 (2012) 605-614. 
[48] C. Karus, M.A. Mondragao, D. Ziemens, C.R. Rose, Astrocytes restrict discharge duration and neuronal sodium loads during recurrent network activity, Glia, 63 (2015) 936-957.

[49] Y. Watanabe, Y. Koide, J. Kimura, Topics on the Na+/Ca2+ exchanger: pharmacological characterization of $\mathrm{Na}+/ \mathrm{Ca} 2+$ exchanger inhibitors, J Pharmacol Sci, $102(2006)$ 7-16.

[50] J. Kimura, T. Watano, M. Kawahara, E. Sakai, J. Yatabe, Direction-independent block of bi-directional $\mathrm{Na}^{+} / \mathrm{Ca}^{2+}$ exchange current by KB-R7943 in guinea-pig cardiac myocytes, Br J Pharmacol, 128 (1999) 969-974.

[51] H. Satoh, K.S. Ginsburg, K. Qing, H. Terada, H. Hayashi, D.M. Bers, KB-R7943 block of $\mathrm{Ca}(2+)$ influx via $\mathrm{Na}(+) / \mathrm{Ca}(2+)$ exchange does not alter twitches or glycoside inotropy but prevents $\mathrm{Ca}(2+)$ overload in rat ventricular myocytes, Circulation, 101 (2000) 1441-1446.

[52] H.J. Hu, S.S. Wang, Y.X. Wang, Y. Liu, X.M. Feng, Y. Shen, L. Zhu, H.Z. Chen, M. Song, Blockade of the forward $\mathrm{Na}(+) / \mathrm{Ca}(2+)$ exchanger suppresses the growth of glioblastoma cells through $\mathrm{Ca}(2+)$-mediated cell death, Br J Pharmacol, 176 (2019) 2691-2707.

[53] K. Boddum, T.P. Jensen, V. Magloire, U. Kristiansen, D.A. Rusakov, I. Pavlov, M.C. Walker, Astrocytic GABA transporter activity modulates excitatory neurotransmission, Nature communications, 7 (2016) 13572.

[54] M. Doengi, D. Hirnet, P. Coulon, H.C. Pape, J.W. Deitmer, C. Lohr, GABA uptakedependent $\mathrm{Ca}(2+)$ signaling in developing olfactory bulb astrocytes, Proc Natl Acad Sci U S A, 106 (2009) 17570-17575. 
[55] J.G. Jackson, M.B. Robinson, Reciprocal Regulation of Mitochondrial Dynamics and Calcium Signaling in Astrocyte Processes, J Neurosci, 35 (2015) 15199-15213.

[56] V.A. Golovina, L.L. Bambrick, P.J. Yarowsky, B.K. Krueger, M.P. Blaustein, Modulation of two functionally distinct $\mathrm{Ca} 2+$ stores in astrocytes: role of the plasmalemmal Na/Ca exchanger, Glia, 16 (1996) 296-305.

[57] J. Meyer, V. Untiet, C. Fahlke, T. Gensch, C.R. Rose, Quantitative determination of cellular $[\mathrm{Na}(+)]$ by fluorescence lifetime imaging with CoroNaGreen, J Gen Physiol, 151 (2019) 1319-1331.

[58] F. Oschmann, K. Mergenthaler, E. Jungnickel, K. Obermayer, Spatial separation of two different pathways accounting for the generation of calcium signals in astrocytes, PLoS Comput Biol, 13 (2017) e1005377.

[59] A.R. Brazhe, A.Y. Verisokin, D.V. Verveyko, D.E. Postnov, Sodium-Calcium Exchanger Can Account for Regenerative $\mathrm{Ca}(2+)$ Entry in Thin Astrocyte Processes, Front Cell Neurosci, 12 (2018) 250.

[60] K. Breslin, J.J. Wade, K. Wong-Lin, J. Harkin, B. Flanagan, H. Van Zalinge, S. Hall, M. Walker, A. Verkhratsky, L. McDaid, Potassium and sodium microdomains in thin astroglial processes: A computational model study, PLoS Comput Biol, 14 (2018) e1006151.

[61] J.J. Wade, K. Breslin, K. Wong-Lin, J. Harkin, B. Flanagan, H. Van Zalinge, S. Hall, M. Dallas, A. Bithell, A. Verkhratsky, L. McDaid, Calcium Microdomain Formation at the Perisynaptic Cradle Due to NCX Reversal: A Computational Study, Front Cell Neurosci, 13 (2019) 185. 
[62] M. Nuriya, M. Yasui, Endfeet serve as diffusion-limited subcellular compartments in astrocytes, J Neurosci, 33 (2013) 3692-3698.

[63] S.P. Yu, D.W. Choi, $\mathrm{Na}(+)-\mathrm{Ca} 2+$ exchange currents in cortical neurons: concomitant forward and reverse operation and effect of glutamate, Eur J Neurosci, 9 (1997) 1273-1281.

[64] K. Takuma, T. Matsuda, H. Hashimoto, J. Kitanaka, S. Asano, Y. Kishida, A. Baba, Role of $\mathrm{Na}(+)-\mathrm{Ca} 2+$ exchanger in agonist-induced $\mathrm{Ca} 2+$ signaling in cultured rat astrocytes, J Neurochem, 67 (1996) 1840-1845.

[65] E. Carafoli, S. Longoni, The plasma membrane in the control of the signaling function of calcium, Society of General Physiologists series, 42 (1987) 21-29.

[66] C.R. Rose, J.Y. Chatton, Astrocyte sodium signaling and neuro-metabolic coupling in the brain, Neuroscience, 323 (2016) 121-134.

[67] L.W. Pappalardo, O.A. Samad, J.A. Black, S.G. Waxman, Voltage-gated sodium channel Nav 1.5 contributes to astrogliosis in an in vitro model of glial injury via reverse $\mathrm{Na}^{+} / \mathrm{Ca}^{2+}$ exchange, Glia, 62 (2014) 1162-1175.

[68] C.L. Floyd, F.A. Gorin, B.G. Lyeth, Mechanical strain injury increases intracellular sodium and reverses $\mathrm{Na}^{+} / \mathrm{Ca}^{2+}$ exchange in cortical astrocytes, Glia, 51 (2005) 3546.

[69] H. Song, S.M. Thompson, M.P. Blaustein, Nanomolar ouabain augments $\mathrm{Ca}^{2+}$ signalling in rat hippocampal neurones and glia, J Physiol, 591 (2013) 1671-1689.

[70] S. Paluzzi, S. Alloisio, S. Zappettini, M. Milanese, L. Raiteri, M. Nobile, G. Bonanno, Adult astroglia is competent for $\mathrm{Na}+/ \mathrm{Ca} 2+$ exchanger-operated 
exocytotic glutamate release triggered by mild depolarization, J Neurochem, 103 (2007) 1196-1207.

[71] S. Kirischuk, H. Kettenmann, A. Verkhratsky, $\mathrm{Na}^{+} / \mathrm{Ca}^{2+}$ exchanger modulates kainate-triggered $\mathrm{Ca}^{2+}$ signaling in Bergmann glial cells in situ, Faseb J, 11 (1997) 566-572.

[72] J.P. Smith, L.A. Cunningham, L.D. Partridge, Coupling of AMPA receptors with the $\mathrm{Na}(+) / \mathrm{Ca}(2+)$ exchanger in cultured rat astrocytes, Brain Res, 887 (2000) 98-109.

[73] J. Yang, H. Yu, D. Zhou, K. Zhu, H. Lou, S. Duan, H. Wang, $\mathrm{Na}(+)-\mathrm{Ca}(2)(+)$ exchanger mediates $\mathrm{ChR} 2$-induced $[\mathrm{Ca}(2)(+)]$ i elevation in astrocytes, Cell Calcium, 58 (2015) 307-316.

[74] C.R. Rose, D. Ziemens, V. Untiet, C. Fahlke, Molecular and cellular physiology of sodium-dependent glutamate transporters, Brain Res Bull, 136 (2018) 13-16.

[75] N.C. Danbolt, Glutamate uptake, Prog Neurobiol, 65 (2001) 1-105.

[76] H. Rojas, C. Colina, M. Ramos, G. Benaim, E.H. Jaffe, C. Caputo, R. DiPolo, $\mathrm{Na}^{+}$ entry via glutamate transporter activates the reverse $\mathrm{Na}^{+} / \mathrm{Ca}^{2+}$ exchange and triggers $\mathrm{Ca}(\mathrm{i})^{2+}$-induced $\mathrm{Ca}^{2+}$ release in rat cerebellar Type-1 astrocytes, J Neurochem, 100 (2007) 1188-1202.

[77] J.G. Jackson, J.C. O'Donnell, H. Takano, D.A. Coulter, M.B. Robinson, Neuronal activity and glutamate uptake decrease mitochondrial mobility in astrocytes and position mitochondria near glutamate transporters, J Neurosci, 34 (2014) 16131624.

[78] T.L. Stephen, N.F. Higgs, D.F. Sheehan, S. Al Awabdh, G. Lopez-Domenech, I.L. Arancibia-Carcamo, J.T. Kittler, Miro1 Regulates Activity-Driven Positioning of 
Mitochondria within Astrocytic Processes Apposed to Synapses to Regulate Intracellular Calcium Signaling, J Neurosci, 35 (2015) 15996-16011.

[79] J.G. Jackson, M.B. Robinson, Regulation of mitochondrial dynamics in astrocytes: Mechanisms, consequences, and unknowns, Glia, 66 (2018) 1213-1234.

[80] M. Belanger, I. Allaman, P.J. Magistretti, Brain energy metabolism: focus on astrocyte-neuron metabolic cooperation, Cell metabolism, 14 (2011) 724-738.

[81] A. Scimemi, Structure, function, and plasticity of GABA transporters, Front Cell Neurosci, 8 (2014) 161.

[82] P. Unichenko, A. Dvorzhak, S. Kirischuk, Transporter-mediated replacement of extracellular glutamate for GABA in the developing murine neocortex, Eur $\mathrm{J}$ Neurosci, 38 (2013) 3580-3588.

[83] J.Y. Chatton, L. Pellerin, P.J. Magistretti, GABA uptake into astrocytes is not associated with significant metabolic cost: implications for brain imaging of inhibitory transmission, Proc Natl Acad Sci U S A, 100 (2003) 12456-12461.

[84] C.R. Rose, B.R. Ransom, Intracellular sodium homeostasis in rat hippocampal astrocytes, J Physiol, 491 (1996) 291-305.

[85] M. Schrodl-Haussel, S.M. Theparambil, J.W. Deitmer, E. Roussa, Regulation of functional expression of the electrogenic sodium bicarbonate cotransporter 1, NBCe1 (SLC4A4), in mouse astrocytes, Glia, 63 (2015) 1226-1239.

[86] E. Turovsky, S.M. Theparambil, V. Kasymov, J.W. Deitmer, A.G. Del Arroyo, G.L. Ackland, J.J. Corneveaux, A.N. Allen, M.J. Huentelman, S. Kasparov, N. Marina, A.V. Gourine, Mechanisms of CO2/H+ Sensitivity of Astrocytes, J Neurosci, 36 (2016) 10750-10758. 
[87] C.R. Rose, A. Verkhratsky, Principles of sodium homeostasis and sodium signalling in astroglia, Glia, 64 (2016) 1611-1627.

[88] F. Boscia, G. Begum, G. Pignataro, R. Sirabella, O. Cuomo, A. Casamassa, D. Sun, L. Annunziato, Glial $\mathrm{Na}(+)$-dependent ion transporters in pathophysiological conditions, Glia, 64 (2016) 1677-1697.

[89] K. Takuma, Y. Ago, T. Matsuda, The glial sodium-calcium exchanger: a new target for nitric oxide-mediated cellular toxicity, Curr Protein Pept Sci, 14 (2013) 43-50.

[90] L. Annunziato, F. Boscia, G. Pignataro, Ionic transporter activity in astrocytes, microglia, and oligodendrocytes during brain ischemia, J Cereb Blood Flow Metab, 33 (2013) 969-982.

[91] J. Luo, Y. Wang, H. Chen, D.B. Kintner, S.W. Cramer, J.K. Gerdts, X. Chen, G.E. Shull, K.D. Philipson, D. Sun, A concerted role of $\mathrm{Na}+-\mathrm{K}+-\mathrm{Cl}-$ cotransporter and $\mathrm{Na}+/ \mathrm{Ca} 2+$ exchanger in ischemic damage, J Cereb Blood Flow Metab, 28 (2008) 737-746.

[92] J. Luo, Y. Wang, X. Chen, H. Chen, D.B. Kintner, G.E. Shull, K.D. Philipson, D. Sun, Increased tolerance to ischemic neuronal damage by knockdown of $\mathrm{Na}+-\mathrm{Ca} 2+$ exchanger isoform 1, Ann N Y Acad Sci, 1099 (2007) 292-305.

[93] P. Molinaro, R. Sirabella, G. Pignataro, T. Petrozziello, A. Secondo, F. Boscia, A. Vinciguerra, O. Cuomo, K.D. Philipson, M. De Felice, R. Di Lauro, G. Di Renzo, L. Annunziato, Neuronal NCX1 overexpression induces stroke resistance while knockout induces vulnerability via Akt, J Cereb Blood Flow Metab, 36 (2016) 1790-1803. 
[94] D. Jeon, K. Chu, K.H. Jung, M. Kim, B.W. Yoon, C.J. Lee, U. Oh, H.S. Shin, $\mathrm{Na}(+) / \mathrm{Ca}(2+)$ exchanger 2 is neuroprotective by exporting $\mathrm{Ca}(2+)$ during a transient focal cerebral ischemia in the mouse, Cell Calcium, 43 (2008) 482-491.

[95] G.J. Jeffs, B.P. Meloni, S. Sokolow, A. Herchuelz, S. Schurmans, N.W. Knuckey, NCX3 knockout mice exhibit increased hippocampal CA1 and CA2 neuronal damage compared to wild-type mice following global cerebral ischemia, Exp Neurol, 210 (2008) 268-273.

[96] D. Bano, K.W. Young, C.J. Guerin, R. Lefeuvre, N.J. Rothwell, L. Naldini, R. Rizzuto, E. Carafoli, P. Nicotera, Cleavage of the plasma membrane $\mathrm{Na}+/ \mathrm{Ca} 2+$ exchanger in excitotoxicity, Cell, 120 (2005) 275-285.

[97] D.B. Kintner, J. Luo, J. Gerdts, A.J. Ballard, G.E. Shull, D. Sun, Role of Na+-K+Cl- cotransport and $\mathrm{Na}+/ \mathrm{Ca} 2+$ exchange in mitochondrial dysfunction in astrocytes following in vitro ischemia, Am J Physiol Cell Physiol, 292 (2007) C1113-1122.

[98] T. Matsuda, N. Arakawa, K. Takuma, Y. Kishida, Y. Kawasaki, M. Sakaue, K. Takahashi, T. Takahashi, T. Suzuki, T. Ota, A. Hamano-Takahashi, M. Onishi, Y. Tanaka, K. Kameo, A. Baba, SEA0400, a novel and selective inhibitor of the Na+$\mathrm{Ca} 2+$ exchanger, attenuates reperfusion injury in the in vitro and in vivo cerebral ischemic models, J Pharmacol Exp Ther, 298 (2001) 249-256.

[99] A. Bondarenko, N. Svichar, M. Chesler, Role of $\mathrm{Na}^{+}-\mathrm{H}^{+}$and $\mathrm{Na}^{+}-\mathrm{Ca}^{2+}$ exchange in hypoxia-related acute astrocyte death, Glia, 49 (2005) 143-152.

[100] J.C. O'Donnell, J.G. Jackson, M.B. Robinson, Transient Oxygen/Glucose Deprivation Causes a Delayed Loss of Mitochondria and Increases Spontaneous Calcium Signaling in Astrocytic Processes, J Neurosci, 36 (2016) 7109-7127. 
[101] N.J. Gerkau, C. Rakers, S. Durry, G. Petzold, C.R. Rose, Reverse NCX attenuates cellular sodium loading in metabolically compromised cortex, Cerebral Cortex 28 (2018) 4264-4280.

4

[102] P. Molinaro, O. Cuomo, G. Pignataro, F. Boscia, R. Sirabella, A. Pannaccione, A. Secondo, A. Scorziello, A. Adornetto, R. Gala, D. Viggiano, S. Sokolow, A. Herchuelz, S. Schurmans, G. Di Renzo, L. Annunziato, Targeted disruption of $\mathrm{Na}^{+} / \mathrm{Ca}^{2+}$ exchanger 3 (NCX3) gene leads to a worsening of ischemic brain damage, J Neurosci, 28 (2008) 1179-1184.

9 


\section{Figure Legends}

Figure 1. A: Schematic representation of an astrocyte expressing sodium/calciumexchanger (NCX) predominantly on distal processes and endfeet. Two transport directions are highlighted: green represents the forward $\left(\mathrm{Ca}^{2+}\right.$ export $/ \mathrm{Na}^{+}$import $)$, red the reverse mode $\left(\mathrm{Ca}^{2+}\right.$ import $/ \mathrm{Na}^{+}$export). The mitochondrial sodium/calcium/lithiumexchanger (NLCX) is highlighted in purple. B: Top: NCX1 positive astrocytes in subcortical layers (scale bar, $30 \mu \mathrm{m}$ ). Bottom left: NCX3 labelling of two astrocyte processes (asp; scale bar, $0.2 \mu \mathrm{m}$ ). Bottom right: NCX3 labelling in astrocytes of the CA1 region of the hippocampus at perivascular astrocyte processes (asp) opposed to a blood vessel (bv) (scale bar, $0.5 \mu \mathrm{m})$. C: Dependence of NCX current density on $\left[\mathrm{Na}^{+}\right]_{\mathrm{i}}$ and $\left[\mathrm{Ca}^{2+}\right]_{\mathrm{i}}$ at a resting membrane potential of $-85 \mathrm{mV}$ (left) and at $-75 \mathrm{mV}$ (right). White line indicates the reversal potential of NCX, defining the border between the reverse and forward mode of the exchanger. Green dots represent $\mathrm{Na}^{+}$concentration of $12 \mathrm{mM}$ and $\mathrm{Ca}^{2+}$ concentration of $80 \mathrm{nM}$, red dots mark a sodium concentration of $17 \mathrm{mM}$. The colour scheme encodes the current amplitude per $\mu \mathrm{m}^{2}$. Taken from (with permission): B: [21] and C: modified from [40].

Figure 2: A: Cytosolic $\mathrm{Na}^{+}$signals induced by glutamatergic stimulation in acute cortical brain slices. Left: image of SR101 (top) and SBFI fluorescence (bottom) taken from layer 2/3 (L 2/3). Right: merge of SR101 and SBFI. Scale bars: $25 \mu \mathrm{m}$. Bottom: somatic $\left[\mathrm{Na}^{+}\right]_{\mathrm{i}}$ transients induced by synaptic stimulation $(10$ pulses $/ 50 \mathrm{~Hz})$, by focal pressure application of glutamate $(1 \mathrm{mM} / 100 \mathrm{~ms})$, and by NMDA-iontophoresis $(50 \mathrm{mM} / 50 \mathrm{~ms})$. 
B: Top: $\left[\mathrm{Ca}^{2+}\right]_{\mathrm{i}}$ transients induced by NMDA-iontophoresis $(50 \mathrm{mM} / 50 \mathrm{~ms})$ in astrocyte processes. Bottom: Means \pm S.E.M. of mono-exponential decay time constants $(\tau)$ of $\left[\mathrm{Ca}^{2+}\right]_{\mathrm{i}}$ changes in response to NMDA under control conditions, with KB-R7943 (KBR; left) or with SEA0400 (SEA; right) and after wash-out of the drugs. **: $0.001 \leq \mathrm{p}<0.01$; *: $0.01 \leq \mathrm{p}<0.05 . \mathrm{C}: \mathrm{Ca}^{2+}$ signalling in astrocyte processes as detected with a genetically-expressed calcium sensor. Effects of the glutamate transport blocker TFBTBOA on $\mathrm{Ca}^{2+}$ signalling are shown in the top trace; the bottom trace illustrates the effect of YM-244769, a blocker of reverse mode NCX. GluT: glutamate transport. D: Top: Individual astrocytes loaded with Fluo-2. Centre: $\left[\mathrm{Ca}^{2+}\right]_{\mathrm{i}}$ transients in astrocytic processes induced by application of GABA. Bottom: in the presence of the NCX blocker KBR7943, GABA-induced $\left[\mathrm{Ca}^{2+}\right]_{\mathrm{i}}$ transients are suppressed. Taken from (with permission): A, B: modified from [40]; C: modified from [55]; D: modified from [53].

Figure 3: Protective role of reverse mode NCX in ischemic conditions. A: Role of NCX knock-out. Top and left: Brains of $\mathrm{NCX}^{-/-}$(A) and wild-type mice (B), subjected to a middle cerebral artery occlusion. Right (C): Quantification of infarction volume. B: Brain sections of wild-type and congenic $\mathrm{NCX}^{+/+}, \mathrm{NCX}^{+/-}$and $\mathrm{NCX}^{-/-}$, subjected to a middle cerebral artery occlusion. The histogram shows the quantification of the infarct volume as compared with the ipsilateral hemisphere. $\mathbf{C}$ : Changes in $\left[\mathrm{Na}^{+}\right]_{\mathrm{i}}$ (left) and $\left[\mathrm{Ca}^{2+}\right]_{\mathrm{i}}$ (right) evoked by a 2-min period of chemical ischemia in control (black trace) and in the presence of KB-R7943 (red traces). The dotted blue lines show estimated $\mathrm{Na}^{+}$export (left) and $\mathrm{Ca}^{2+}$ import (right) through NCX. Taken from (with permission): A: [94]; B: [102], Copyright [2008] Society for Neuroscience; C: modified from [101]. 
Figure 4: Schematic illustration of NCX operating in forward or reverse mode. A: At low intracellular $\mathrm{Na}^{+}$concentrations $(\sim 12 \mathrm{mM}) \mathrm{NCX}$ operates in forward mode (indicated by green arrow/arrowheads). When $\mathrm{Ca}^{2+}$ rises in the cytosol, $\mathrm{NCX}$ expels $\mathrm{Ca}^{2+}$, contributing to the recovery of $\mathrm{Ca}^{2+}$ signals. B: At higher $\left[\mathrm{Na}^{+}\right]_{\mathrm{i}}(\sim 17 \mathrm{mM})$, induced by e.g. $\mathrm{Na}^{+}$-driven uptake of neurotransmitters (GluT or GAT), by $\mathrm{Na}^{+}-\mathrm{HCO}_{3}{ }^{-}$-co-transport (NBC), or by channel mediated $\mathrm{Na}^{+}$influx through ionotropic receptors (iGluR), acidsensing ion channels (ASICs), purinoceptors (P2X) or transient receptor potential channels (TRP), NCX will operate in reverse mode (indicated by red arrow/arrowheads). This results in export of $\mathrm{Na}^{+}$, and import of $\mathrm{Ca}^{2+}$. Reverse NCX thereby contributes to local $\mathrm{Ca}^{2+}$ signalling in astrocytes. 
Aig. 1

B
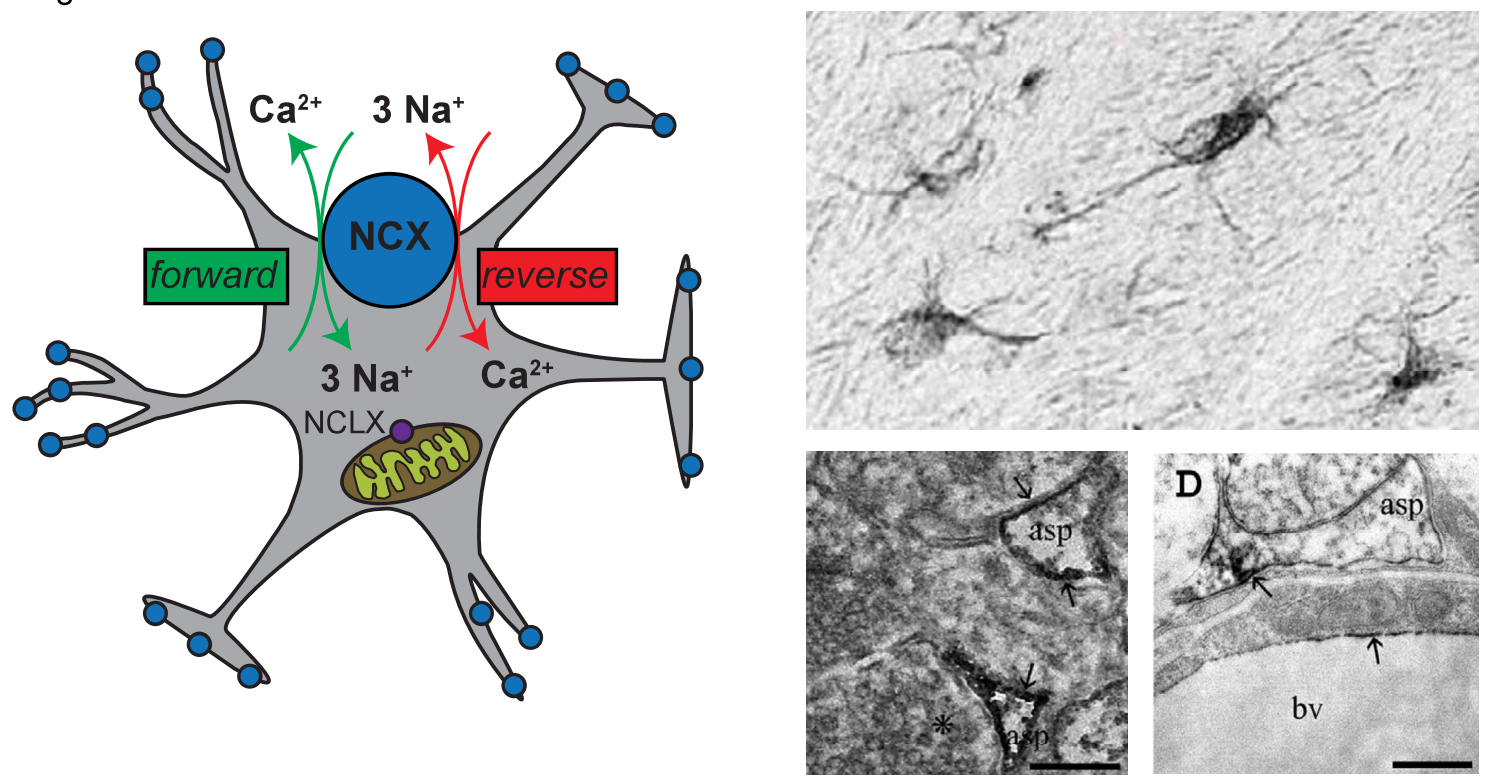

C
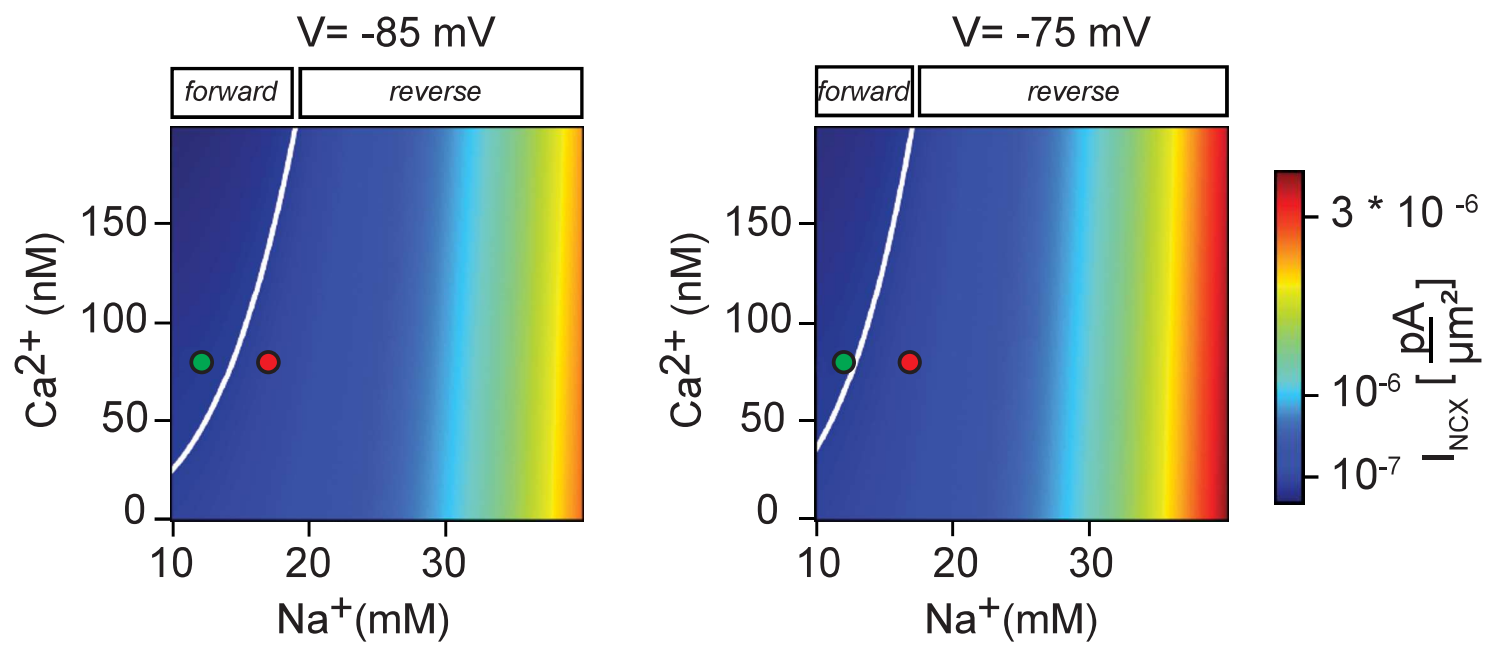

Fig.1

Christine R. Rose, Daniel Ziemens \& Alexei Verkhratsky 
Aigg Rutamate-related sodium transients

cortex

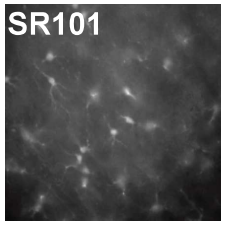

SBFI
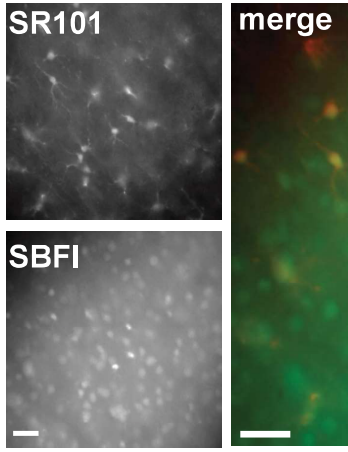

sodium

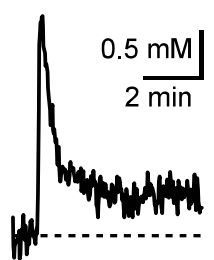

$\Delta$ syn.stim.
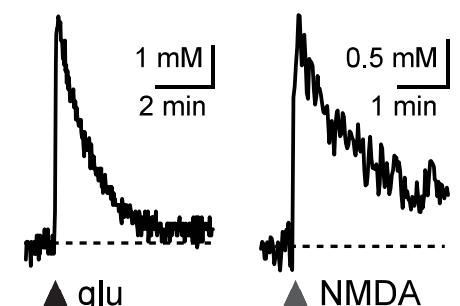

L1
B NCX reversal driven by NMDAR calcium process

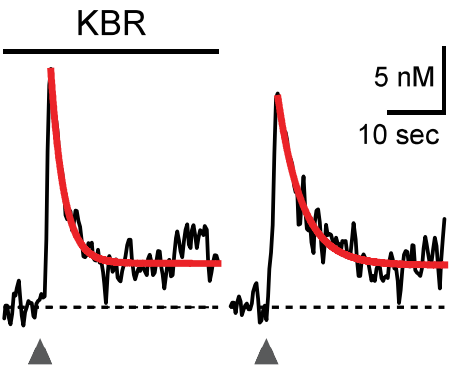

$\triangle$ NMDA
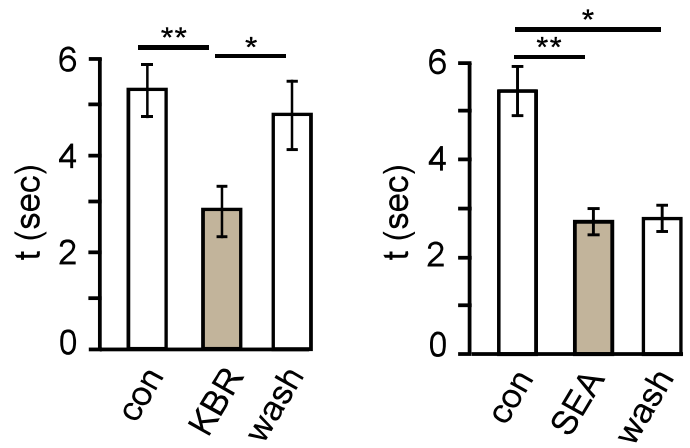

D NCX reversal driven by GAT
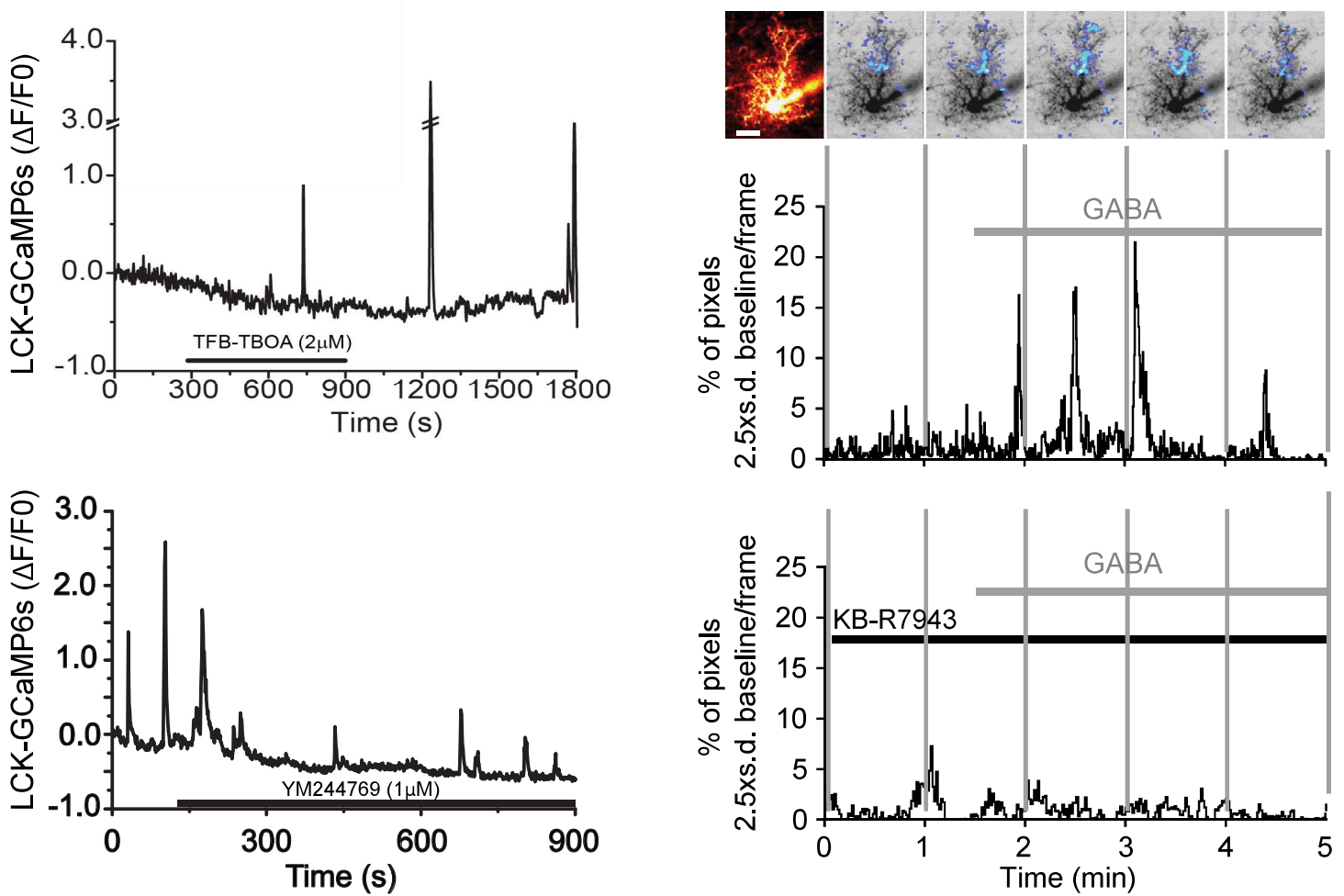

Fig.2

Christine R. Rose, Daniel Ziemens \& Alexei Verkhratsky 
Fig.3

A NCX2 is neuroprotective

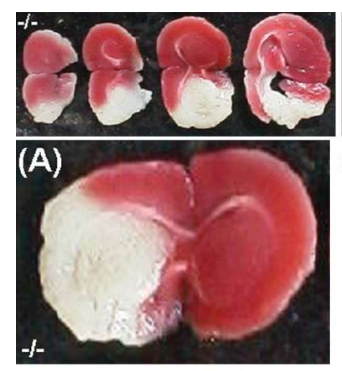

(B)

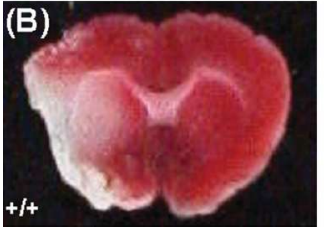

(C)

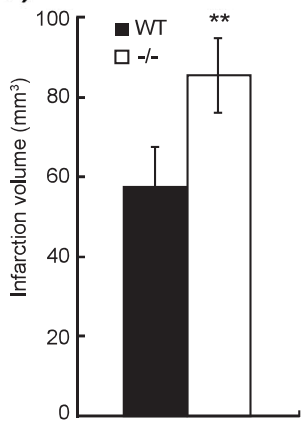

C NCX reversal during chemical ischemia sodium

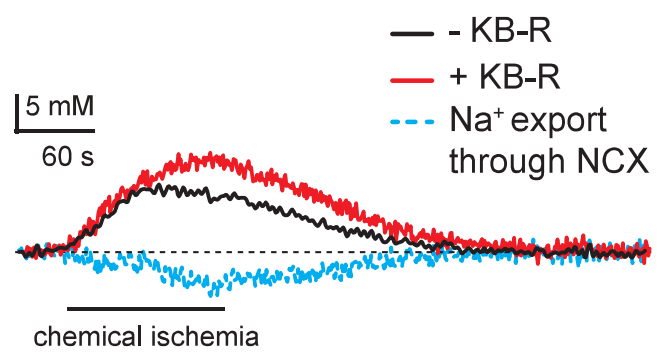

B NCX3 is neuroprotective

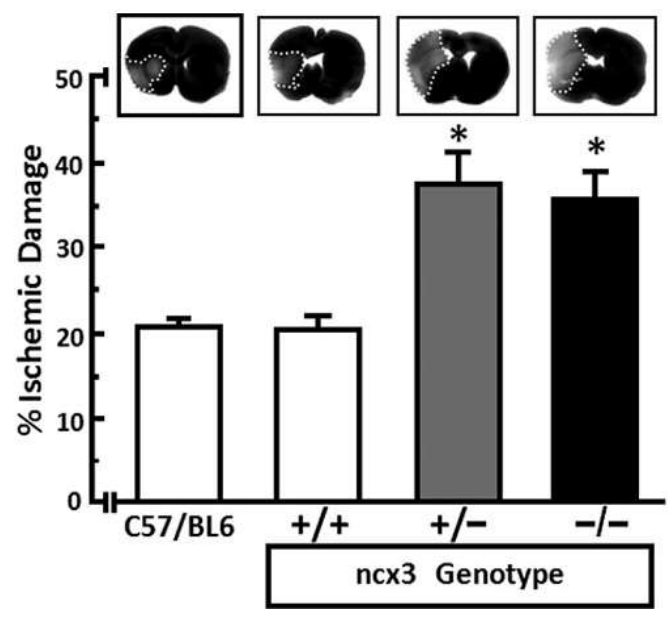

calcium

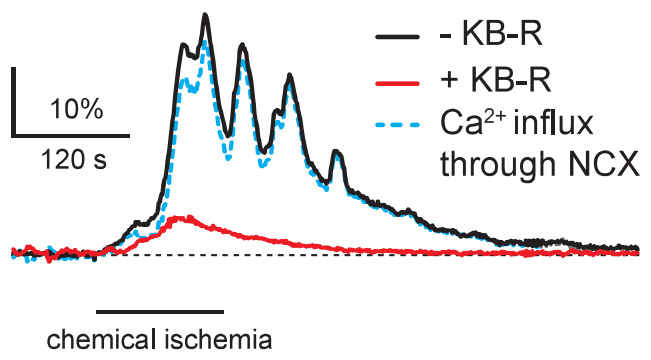

Fig.3

Christine R. Rose, Daniel Ziemens \& Alexei Verkhratsky 

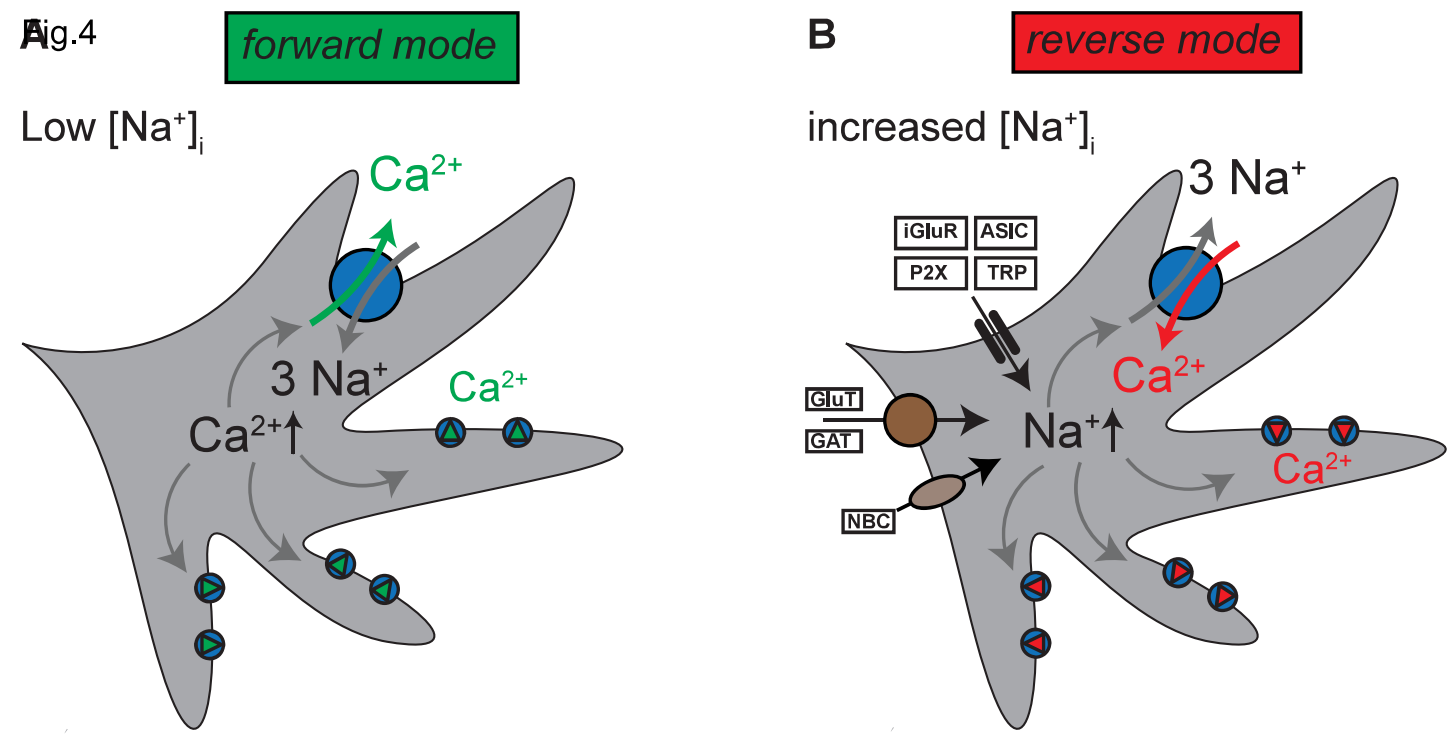

Fig.4

Christine R. Rose, Daniel Ziemens \& Alexei Verkhratsky 
Author Contributions Section
\[ \text { Authors contributed equally to the conceptualisation, writing and editing of this paper } \]

Authors contributed equally to the conceptualisation, writing and editing of this paper 